\title{
Trends and Patterns of The Internet Use During School Holidays
}

\author{
Khalid $^{1 \text { * }}$, Indri Sudanawati Rozas ${ }^{2)}$, Dwi Rolliawati ${ }^{3)}$ \\ 1)2)3)UIN Sunan Ampel Surabaya, Indonesia \\ Jl. Ahmad Yani No 117, Surabaya \\ ${ }^{1)}$ khalid@uinsby.ac.id, ${ }^{2)}$ indrisrozas@uinsby.ac.id, ${ }^{3)}$ dwi_roll@uinsby.ac.id
}

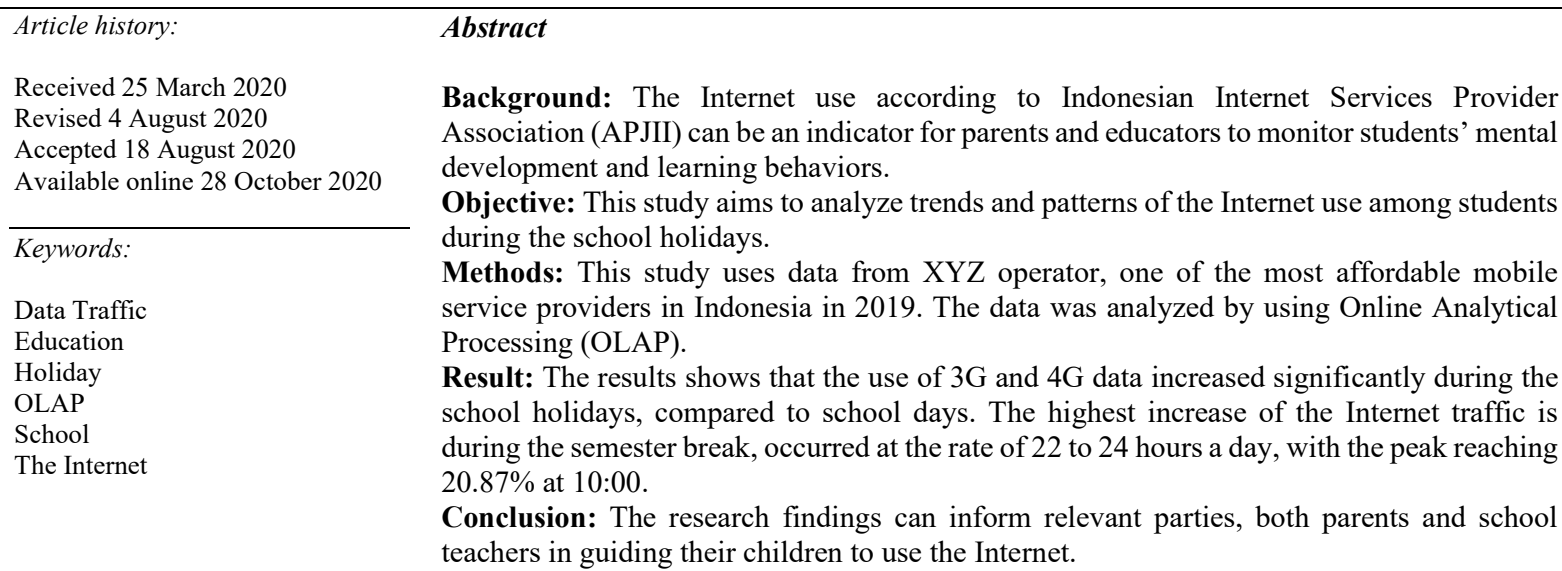

\section{INTRODUCTION}

In the era of information technology or the Internet of Thing (IoT), business, commerce, trading, communication, and networking is now shifting from conventional to digital mode. Despite the convenience, there is also a threat, such as the impact on the younger generation. Research has shown the negative sides of the Internet use on children if not monitored and controlled [1-4]. Research shows that most teenagers spend 1 to 8 hours per day on the Internet. Some may even experience the fear of missing out (FOMO) when they are off-line. They assume that the 'addiction' is normal [3] when in fact, the Internet addiction highly influences the time management and may cause withdrawal and other behavioral problems [4]. Screen time also greatly affects eye fatigue [5] and obesity [6] at the age of children and adolescents. Aside from this, there is also risk to mental health because the Internet users are prone to cyberbullying [7] and pornography [8].

Based on survey conducted by APJII (Indonesian Association for the Internet Service Providers), in 2018 the Internet users in Indonesia reached $64.80 \%$ of the total population, raising $54.68 \%$ in 2017 , and was dominated by the millennial generation (those who were born in or after 2000). Further in the APJII survey, 91\% of the Internet users are aged $15-19$ years; and $88.5 \%$ are aged $20-24$ years. Meanwhile, the education level shows that: $41.4 \%$ elementary schools, $80.4 \%$ junior high school, $90.2 \%$ senior high school, and then $92.6 \%$ are university students [9].

Referring to BPS (Indonesian Central Bureau of Statistics) data [10], regarding the gross rate in education participant based on its level, elementary student is the biggest participant number compared to junior and senior high school student, as presented in Table 1.

Excessive use of the Internet not only affects teenagers but also adolescents (productive working age), such as by decreasing productivity [11-13]. As an illustration, the data below in Table 2 shows the comparison between the competitiveness index scores issued by the World Economic Forum [14] and INSEAD Business School [15], reading scores issued by Program for International Students Assessment (PISA) [16], as well as data on usage and speed of the Internet from several countries [17] [18].

\footnotetext{
${ }^{*}$ Corresponding author
} 
TABLE 1

COMPARISON FOR EDUCATION PARTICIPANT VS THE INTERNET USER IN EACH EDUCATION LEVEL

\begin{tabular}{lcr}
\hline \multicolumn{1}{c}{ Level } & Gross rate participant BPS 2018 (\%) [10] & The Internet user APJII 2018 (\%) [9] \\
\hline Elementary & 38.78 & 41.4 \\
Junior High School & 32.63 & 80.4 \\
Senior High School & 28.58 & 90.2 \\
\hline
\end{tabular}

In Indonesia, there have not been many research studies on the analysis of the Internet use behavior. If there are, they mostly use descriptive qualitative data [19] [20], which analyze the behavior without further examining the Internet data use trend. The current research aims to fill the gap in the literature. Data was collected from one of telecommunication cellular operator in Indonesia throughout 2019. Trends and patterns of the Internet use during school active days and school holidays was analyzed by using OLAP (Online Analytical Processing). OLAP method was selected because it allows easy and interactive explorative data analysis at various levels by following and applying a multidimensional approach [21-23]. The result of this research could give a clear description of the Internet use by school students so parents and teachers could provide guidance to them.

TABLE 2

DATA Global COMPETITIVENESS INDEX, READING SCORE, AND Digital YeARBOOK

\begin{tabular}{|c|c|c|c|c|c|c|c|c|c|c|}
\hline \multirow[t]{3}{*}{ Country Rank } & \multirow{3}{*}{$\begin{array}{c}\text { Global } \\
\text { Competitiv } \\
\text { eness Index } \\
4.02019 \\
\text { edition } \\
\text { Klaus } \\
\text { Schwab, } \\
\text { World } \\
\text { Economic } \\
\text { Forum }\end{array}$} & \multirow{3}{*}{$\begin{array}{l}\text { The Global } \\
\text { Talent } \\
\text { Competitive- } \\
\text { ness Index } \\
\text { INSEAD, the } \\
\text { Adecco Group, } \\
\text { and Tata } \\
\text { Communi- } \\
\text { cations }\end{array}$} & \multirow{3}{*}{$\begin{array}{c}\text { Mean } \\
\text { reading score in } \\
\text { PISA 2018, } \\
\text { Organization } \\
\text { for Economic } \\
\text { Co-operation, } \\
\text { and } \\
\text { Development } \\
\\
\text { (world } \\
\text { average: } 487 \text { ) }\end{array}$} & \multicolumn{7}{|c|}{$\begin{array}{l}\text { DIGITAL 2019, Global Digital Yearbook } \\
\text { Simon Kemp, We are Social Ltd }\end{array}$} \\
\hline & & & & $\begin{array}{c}\text { Percentag } \\
\text { e of the } \\
\text { total } \\
\text { popula- } \\
\text { tion that } \\
\text { uses the } \\
\text { Internet } \\
\\
\text { (world } \\
\text { average: } \\
57 \text { ) }\end{array}$ & $\begin{array}{l}\text { Time Per } \\
\text { Day Spent } \\
\text { Using the } \\
\text { Internet via } \\
\text { any device }\end{array}$ & $\begin{array}{c}\text { Time Per } \\
\text { Day } \\
\text { Spent } \\
\text { Using } \\
\text { Mobile } \\
\text { the } \\
\text { Internet } \\
\\
\text { (world } \\
\text { average: } \\
03.14 \text { ) }\end{array}$ & $\begin{array}{l}\text { Average } \\
\text { Fixed the } \\
\text { Internet } \\
\text { Connec- } \\
\text { tion Speeds }\end{array}$ & $\begin{array}{l}\text { Average } \\
\text { Mobile the } \\
\text { Internet } \\
\text { Connection } \\
\text { Speeds }\end{array}$ & $\begin{array}{c}\text { Time per } \\
\text { day spent } \\
\text { using } \\
\text { social } \\
\text { media }\end{array}$ & $\begin{array}{c}\text { Indivi- } \\
\text { dual Use } \\
\text { of Social } \\
\text { Media } \\
\text { for Work }\end{array}$ \\
\hline & & & & $\%$ & hour & hour & MBPS & MBPS & Hour & $\%$ \\
\hline Singapore & 1 & 2 & 549 & 54 & 07.02 & 02.58 & 190.9 & 61.0 & 02.08 & 21 \\
\hline Switzerland & 5 & 1 & 484 & 95 & 04.58 & 01.54 & 104.2 & 47.5 & 01.16 & 20 \\
\hline Japan & 6 & 22 & 504 & 94 & 03.45 & 01.25 & 91.8 & 30.9 & 00.36 & 6 \\
\hline China & 12 & 45 & 555 & 57 & 05.52 & 03.19 & 89.2 & 29.4 & 01.57 & 24 \\
\hline Malaysia & 27 & 27 & 415 & 80 & 08.05 & 04.02 & 63.5 & 19.9 & 02.58 & 32 \\
\hline Indonesia & 50 & 67 & 371 & 54 & 08.36 & 04.35 & 15.5 & 10.5 & 03.26 & 37 \\
\hline Philippines & 64 & 58 & 340 & 71 & 10.02 & 04.58 & 19.0 & 15.1 & 04.12 & 34 \\
\hline
\end{tabular}

: highest in the world

: lowest in the world

\section{METHODS}

This research is descriptive quantitative with five main steps: establish the context, collecting data, pre-processing, data processing using OLAP, and result analysis, summarise in the chart below (Fig. 1).

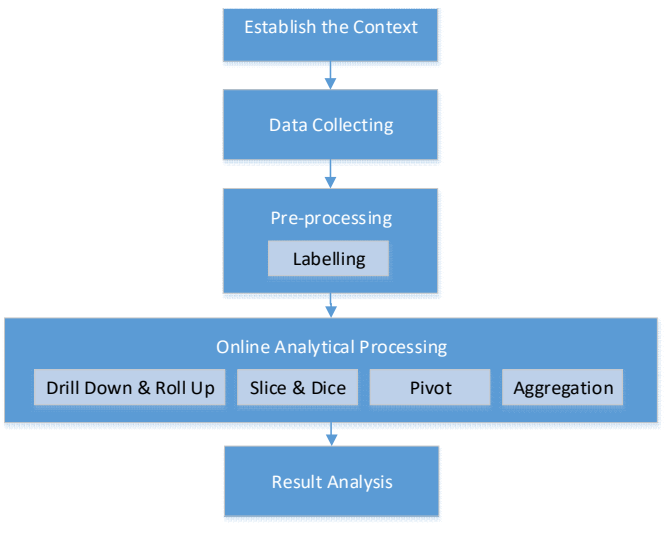

Fig. 1 Research Methodology 


\section{Establish the context}

The data of the Internet use was collected from cellullar telecommunication operator (XYZ operator) analyzed against the academic calendar, with the scope of study covering East Java Province only. This was to avoid too many variables. Besides, the permission to use the data had been granted by the local authorities. In the 2018 APJII survey, the number of users in Java was the highest compared to other islands, which was $55.7 \%$, then followed by Sumatra $21.6 \%$. East Java alone ranked third with $13.5 \%$, after West Java (16.7\%) and Central Java (14.3\%). With such number of Internet users, data from East Java is considered reasonable to represent the trends and patterns of the Internet use in Indonesia. The educational school calendar year are 2018/2019 and 2019/2020 starting from 1 January to 31 December 2019 (see Fig. 2). With this context, the process continues to data collection phase.

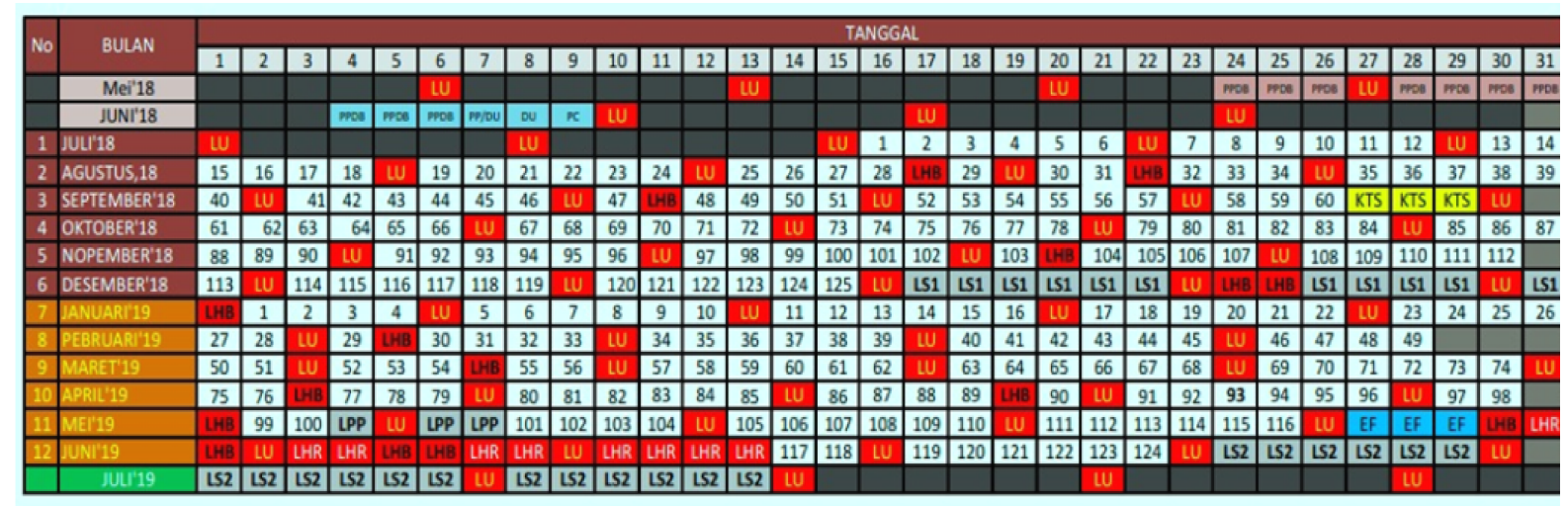

Fig. 2 East Java province, educational school calendar year 2018/2019

\section{Data Collecting}

The selected operator had a market share of $12 \%$, and considered to be one of cheapest operator in Indonesia. The data being collected is the measurements of hourly the Internet payload traffic data for all sites' Base Transceiver Stations (BTS) in East Java.

\section{3. $\quad$ Pre-processing}

To be processed by using OLAP, data was prepared in advance by date labeling process, which is to give label status to all dates for a year by adding activity list from educational school calendar published by East Java educational authority institution. Data labeling aims to observe the trends and patterns of the Internet use between the school active days and the school holidays in accordance with the educational school calendar (see Fig. 2).
a. Active school days
b. Effective Facultative days (EF)
c. Public Holidays (LHB)
d. Religious Ceremonial Holiday (LHR)
e. Fasting Initial Holiday (LPP)
f. Semester Break (LS1 \& LS2)
g. Common Holiday-Sunday (LU)

4. Online Analytical Processing (OLAP)

Data was processed by using OLAP, a database technology that has been optimized for querying and reporting. OLAP uses data sources from transactional database (Online Transactional Processing (OLTP) that are extracted, transformed and loaded (ETL) and stored in a data warehouse [24]. OLAP data is derived from historical data and aggregated into structures or schemes which allows sophisticated analysis. OLAP data is also organized hierarchically and stored in a cube form, and not in tables [25], [26]. It is such an advanced sophisticated technology that uses multidimensional structures to provide a quick data access for data analysis. In this research, the OLAP process design is presented in Fig. 3. 


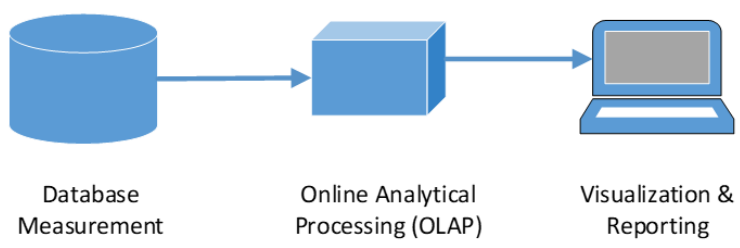

Fig. 3 OLAP process

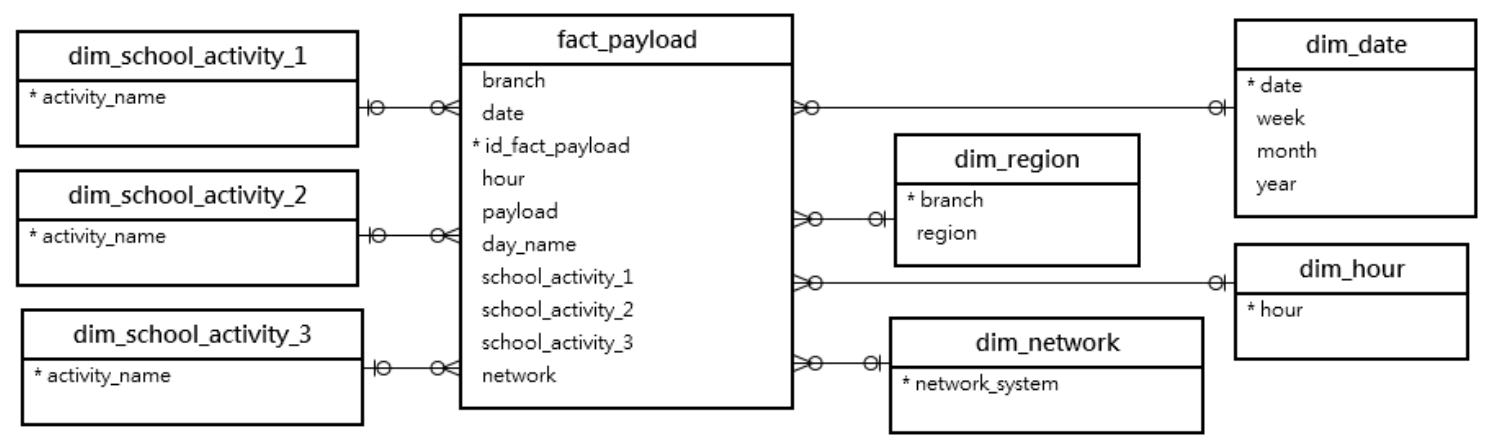

Fig. 4 Multidimentional scheme

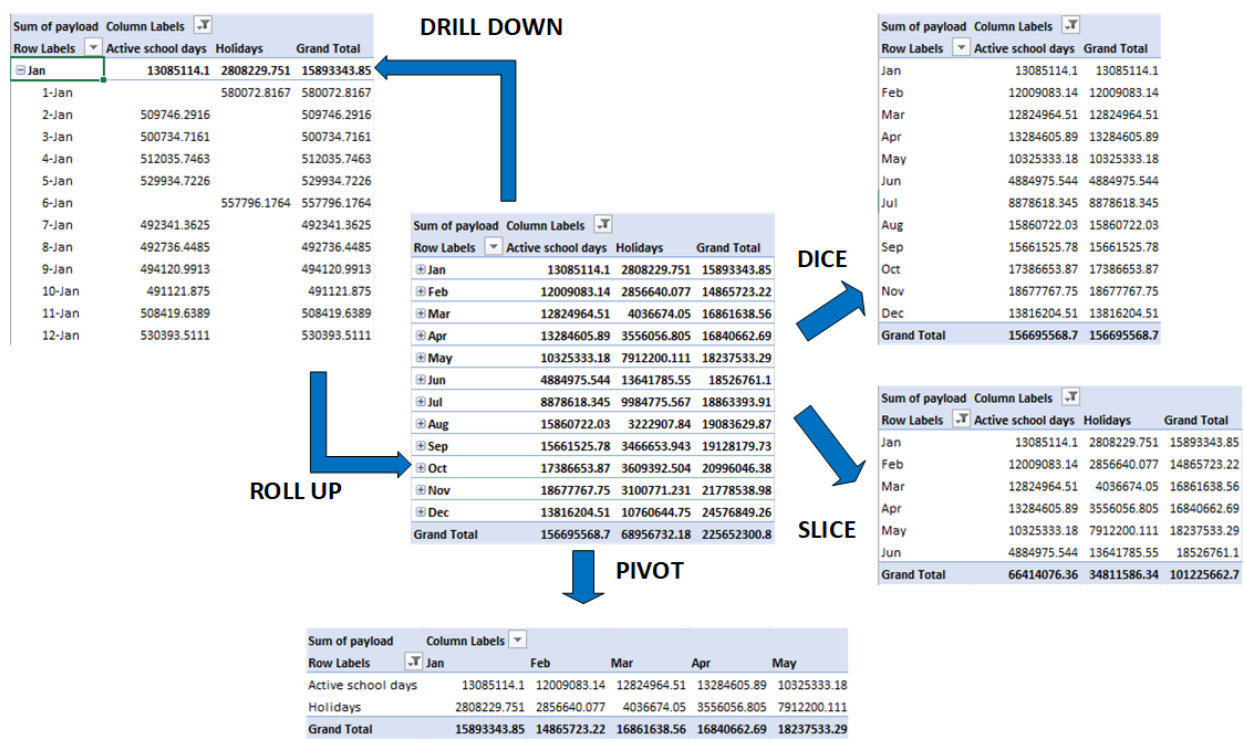

Fig. 5 Example OLAP operation

The database measurement is used to store the multidimensional data of all network's key performance index (KPI) measurement. The multidimensional scheme of the database measurement is presented in Fig 4. Transaction data is stored to the fine-grained level per hour. When traffic payload data is collected, it is processed by using OLAP, with the oprations: Roll up-drill down, slice-dice, agregration and pivoting as ilustrated in Fig. 5.

Roll up-drill down aims to increase or decrease the level/hierarchy of summary and data aggregation. In this study, aggregation level is determined at hourly level (hourly average), then to be analyzed and compared the Internet use trends and patterns during the whole day, between school active days and holidays. Slice and dice aim to determine one and/or two dimensions of data chosen to be sub-cube being analyzed. In this case, a province or a branch is determined for an area dimension, while date, day, and hours are determined for time dimension. Aggregate operation is the process of determining the desired summary type. The aggregate chosen is average, since the number of days between school active days and holidays are quite imbalance. Pivot operation is applied to rotate the cube axis to 
obtain other analysis viewpoints. Visualization and reporting are used to present and compare data of the Internet use patterns in accordance with the output results of OLAP process in the previous stage.

The database measurement is used to store the multidimensional data of all network's key performance index (KPI) measurement. The multidimensional scheme of the database measurement is presented in Fig. 4. Transaction data is stored to the fine-grained level per hour. When traffic payload data is collected, it is processed by using OLAP, with the oprations: Roll up-drill down, slice-dice, agregration and pivoting as ilustrated in Fig. 5.

Roll up-drill down aims to increase or decrease the level/hierarchy of summary and data aggregation. In this study, aggregation level is determined at hourly level (hourly average), then to be analyzed and compared the Internet use trends and patterns during the whole day, between school active days and holidays. Slice and dice aim to determine one and/or two dimensions of data chosen to be sub-cube being analyzed. In this case, a province or a branch is determined for an area dimension, while date, day, and hours are determined for time dimension. Aggregate operation is the process of determining the desired summary type. The aggregate chosen is average, since the number of days between school active days and holidays are quite imbalance. Pivot operation is applied to rotate the cube axis to obtain other analysis viewpoints. Visualization and reporting are used to present and compare data of the Internet use patterns in accordance with the output results of OLAP process in the previous stage.

\section{Result Analysis}

After all data processing steps are completed, the results in the form of graphs and tables will be analyzed based on 4 (four) aspects, as follow:

a. The Internet traffic payload trends and patterns between active school days $($ asd $)$ and holidays $(h)$

The percentage of difference/delta in this section is referred to as delta $A$ as shown in (1), which compares the difference in usage between as and $h$ based on the time period.

$$
\operatorname{delta} A=\left(\frac{h}{a s d} \times 100\right)-100
$$

b. The Internet traffic payload trends and patterns between active school days ( $a s)$ and semester break $(s b)$

The percentage of difference/delta in this section is referred to as delta $B$ as shown in (2), which compares the difference in usage between $a s$ and $h$ based on the time period.

$$
\operatorname{delta} B=\left(\frac{s b}{a s d} \times 100\right)-100
$$

c. The Internet traffic payload trends and patterns between active school days (as) and initial fasting holiday (ifh) The percentage of difference/delta in this section is referred to as delta $C$ as shown in (3), which compares the difference in usage between as and ifh based on the time period.

$$
\operatorname{delta} C=\left(\frac{\text { ifh }}{\text { asd }} \times 100\right)-100
$$

d. The Internet traffic payload trends and patterns between semester break $(s b)$ and non-semester break $(n s b)$

The percentage of difference/delta in this section is referred to as delta $D$ as shown in (4), which compares the difference in usage between $s b$ and $n s b$ based on the time period.

$$
\text { delta } D=\left(\frac{n s b}{s b} \times 100\right)-100
$$

It is expected that the results of this study could clearly illustrate the data on the Internet use during school holidays.

\section{RESULTS}

After performing roll-up or drill-down as ilustrated in Fig. 6, slice-dice as ilustrated in Fig. 8 and pivoting as ilustrated in Fig. 7, an analysis was then carried out. The following graphs and tables show the difference of trends and patterns in the Internet use presented on an hourly base. This is the fundamental difference between this study and previous studies with similar topic themes [19][20]. 


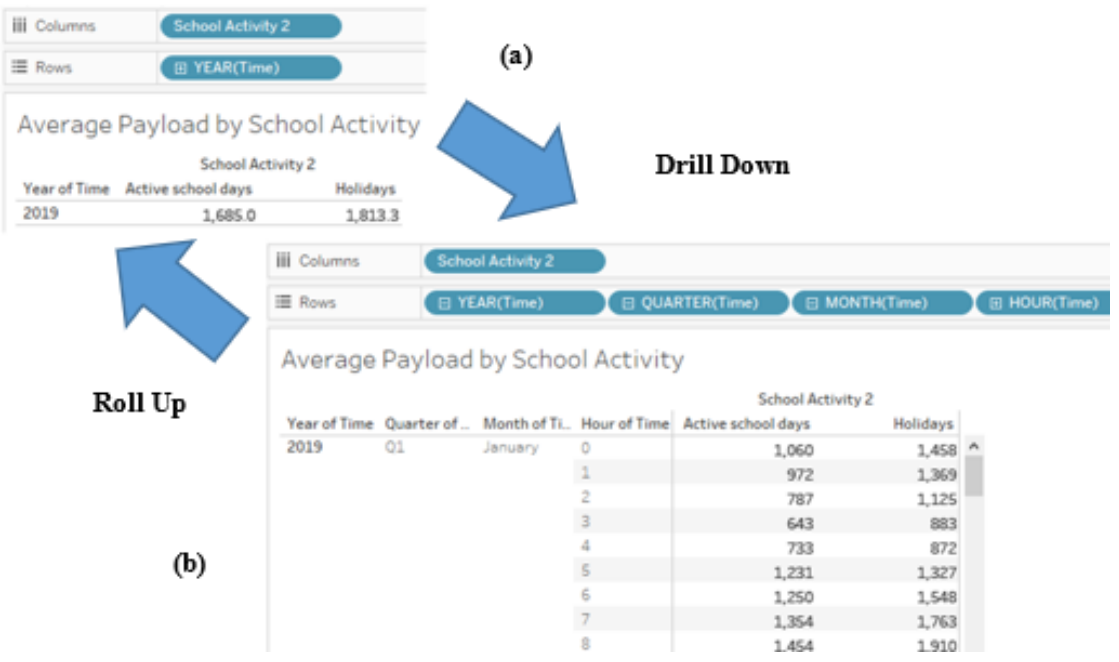

Fig. 6 Drill Down (a to b) - Roll UP (b to a)

\begin{tabular}{|c|c|c|c|c|}
\hline iii Columns & (⿴囗十) HOUR(Time) & & & \\
\hline :E Rows & (由 MONTH(Time) & School A & vity 1 & \\
\hline \multicolumn{5}{|c|}{ Payload by school Activity } \\
\hline Month of Ti.. & School Activity 1 & 0 & 1 & 2 \\
\hline \multirow[t]{3}{*}{ January } & Active school days & 1,060 & 972 & 787 \\
\hline & Common Holiday-Sunday & 1,253 & 1,170 & 970 \\
\hline & Public Holidays & 2,687 & 2,563 & 2,054 \\
\hline \multirow[t]{3}{*}{ February } & Active school days & 1,070 & 964 & 776 \\
\hline & Common Holiday-Sunday & 1,249 & 1,153 & 949 \\
\hline & Public Holidays & 1,087 & 1,018 & 865 \\
\hline \multirow[t]{3}{*}{ March } & Active school days & 1,062 & 935 & 717 \\
\hline & Common Holiday-Sunday & 1,276 & 1,122 & 912 \\
\hline & Public Holidays & 1,112 & 964 & 775 \\
\hline
\end{tabular}

(a)

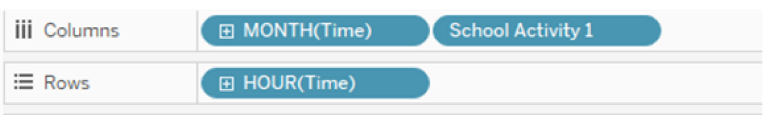

Payload by school Activity

\begin{tabular}{|c|c|c|c|c|c|}
\hline \multirow[b]{2}{*}{ Hour of Time } & \multicolumn{3}{|c|}{ January } & \multicolumn{2}{|r|}{ February } \\
\hline & Active scho.. & Common H.. & Public Holi.. & Active scho.. & Common H.. \\
\hline 0 & 1,060 & 1,253 & 2,687 & 1,070 & 1,249 \\
\hline 1 & 972 & 1,170 & 2,563 & 964 & 1,153 \\
\hline 2 & 787 & 970 & 2,054 & 776 & 949 \\
\hline 3 & 643 & 784 & 1,480 & 646 & 768 \\
\hline 4 & 733 & 804 & 1,276 & 717 & 780 \\
\hline 5 & 1,231 & 1,263 & 1,712 & 1,237 & 1,288 \\
\hline 6 & 1,250 & 1,478 & 1,966 & 1,298 & 1,550 \\
\hline 7 & 1,354 & 1,665 & 2,350 & 1,393 & 1,724 \\
\hline 8 & 1,454 & 1,786 & 2,651 & 1,477 & 1,799 \\
\hline
\end{tabular}

(b)

Fig. 7 Pivot ((a to b) or (b to a))

a. The Internet traffic payload trends and patterns between active school days and holidays

School holidays are defined as all types of holidays, including public holidays, religious holidays, the beginning of fasting month holiday, semester break, and other holidays and Sundays. The results of data processing are in Table 3. The percentage figure of traffic delta is calculated by delta traffic of School Holidays and School Active Days, then divided by School Active Days traffic. Such traffic delta is presented in the form of a percentage to give clear description on differences in trends \& patterns of data the Internet use.

Table 3 shows that the peak time of the Internet use per day in East Java both in active days and holidays is at 20:00. Meanwhile the lowest point of the Internet use is at 3:00. As illustrated in Fig. 9 (A), in general, the Internet use in school active days share similar trends and patterns to the Internet use during school holidays, only there is evidently significant increase of the Internet payload traffic during school holidays. The traffic increment per day starting at 00.00 is $14.95 \%$ and ending at 23.00 is $3.26 \%$. While the highest increment is at 3:00 to $4: 00$ which is $24.24 \%$ and the lowest increment are at 5:00 to $6: 00$ and 19:00 to $20: 00$ which is $-0.33 \%$.

As shown in Fig. 3, the increment point of the Internet use is 00:00 - 04:00 and 06:00 - 16:00. We may conclude that during school holidays, during the bedtime and the daytime when parents are working, children/teenagers spend their time browsing the Internet. By observing the chart diagram, we assume that at midnight, they are still awake surfing on the Internet since there is no school rush the next morning. 
(b)
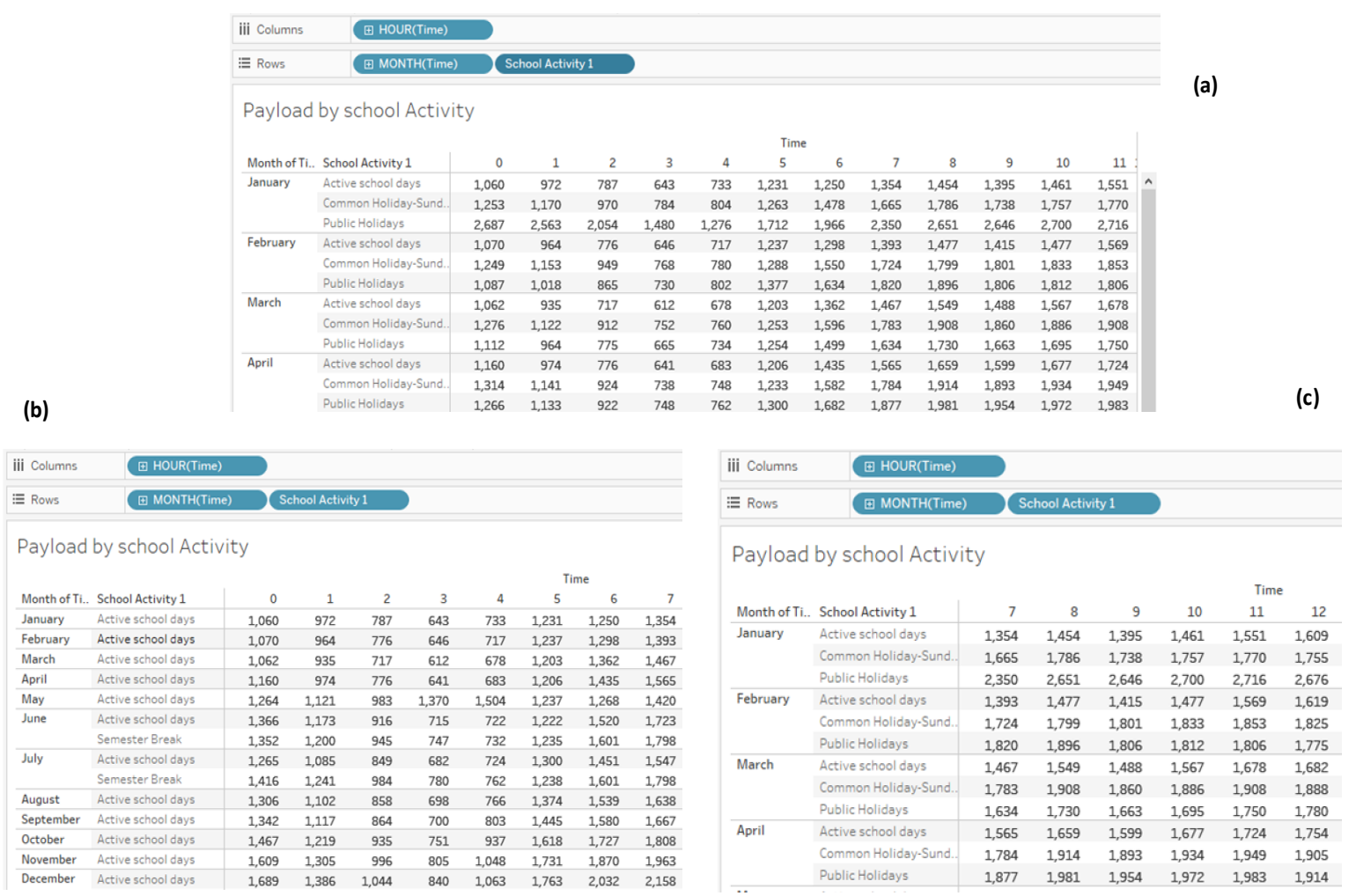

Fig. 8 Slice (a to b) - Dice (a to c)

TABLE 3

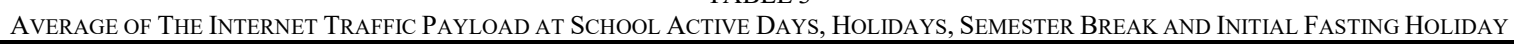

\begin{tabular}{|c|c|c|c|c|c|c|c|}
\hline \multirow{2}{*}{ Time } & \multicolumn{4}{|c|}{ " Average of The Internet traffic Payload (GB) } & \multicolumn{3}{|c|}{ Traffic Delta (\%) } \\
\hline & School Active Days & School Holidays & Semester Break & Initial Fasting holiday & Delta A & Delta B & Delta $\mathrm{C}$ \\
\hline 1 & 2 & 3 & 4 & 5 & $6=((3 / 2) * 100)-100$ & $7=((4 / 2) * 100)-100$ & $8=((5 / 2) * 100)-100$ \\
\hline 0:00:00 & $1.297,94$ & $1.491,99$ & $1.501,58$ & $1.133,26$ & 14,95 & 15,69 & $-12,69$ \\
\hline 1:00:00 & $1.105,47$ & $1.308,51$ & $1.311,87$ & 982,52 & 18,37 & 18,67 & $-11,12$ \\
\hline 2:00:00 & 868,24 & $1.062,51$ & $1.035,90$ & 883,08 & 22,38 & 19,31 & 1,71 \\
\hline 3:00:00 & 747,38 & 928,52 & 818,42 & $1.247,21$ & 24,24 & 9,51 & 66,88 \\
\hline 4:00:00 & 860,09 & 970,00 & 832,58 & $1.283,44$ & 12,78 & $-3,20$ & 49,22 \\
\hline $6: 00: 00$ & $1.528,92$ & $1.688,54$ & $1.749,44$ & $1.332,67$ & 10,44 & 14,42 & $-12,84$ \\
\hline 7:00:00 & $1.636,72$ & $1.913,82$ & $1.967,95$ & $1.571,69$ & 16,93 & 20,24 & $-3,97$ \\
\hline 8:00:00 & $1.738,87$ & $2.061,04$ & $2.096,57$ & $1.756,19$ & 18,53 & 20,57 & 1,00 \\
\hline 9:00:00 & $1.706,57$ & $2.048,37$ & $2.062,75$ & $1.795,78$ & 20,03 & 20,87 & 5,23 \\
\hline 10:00:00 & $1.792,28$ & $2.097,93$ & $2.120,78$ & $1.884,83$ & 17,05 & 18,33 & 5,16 \\
\hline 11:00:00 & $1.888,28$ & $2.122,17$ & $2.162,44$ & $1.895,42$ & 12,39 & 14,52 & 0,38 \\
\hline 12:00:00 & $1.936,25$ & $2.085,32$ & $2.155,17$ & $1.907,30$ & 7,70 & 11,31 & $-1,50$ \\
\hline 13:00:00 & $1.882,27$ & $2.020,00$ & $2.082,60$ & $1.818,91$ & 7,32 & 10,64 & $-3,37$ \\
\hline 15:00:00 & $1.843,67$ & $1.912,96$ & $1.912,06$ & $1.724,30$ & 3,76 & 3,71 & $-6,47$ \\
\hline 16:00:00 & $1.893,79$ & $1.924,93$ & $1.938,69$ & $1.734,35$ & 1,64 & 2,37 & $-8,42$ \\
\hline 17:00:00 & $2.029,63$ & $2.025,34$ & $2.087,84$ & $1.716,94$ & $-0,21$ & 2,87 & $-15,41$ \\
\hline 18:00:00 & $2.138,91$ & $2.152,87$ & $2.255,44$ & $1.973,30$ & 0,65 & 5,45 & $-7,74$ \\
\hline 19:00:00 & $2.184,54$ & $2.177,44$ & $2.296,14$ & $1.880,88$ & $-0,33$ & 5,11 & $-13,90$ \\
\hline 20:00:00 & $2.223,62$ & $2.220,97$ & $2.326,50$ & $2.028,16$ & $-0,12$ & 4,63 & $-8,79$ \\
\hline 21:00:00 & $2.194,42$ & $2.194,72$ & $2.308,81$ & $2.017,89$ & 0,01 & 5,21 & $-8,04$ \\
\hline $22: 00: 00$ & $2.006,20$ & $2.031,06$ & $2.164,44$ & $1.876,43$ & 1,24 & 7,89 & $-6,47$ \\
\hline 23:00:00 & $1.673,06$ & $1.727,61$ & $1.867,14$ & $1.569,13$ & 3,26 & 11,60 & $-6,21$ \\
\hline
\end{tabular}




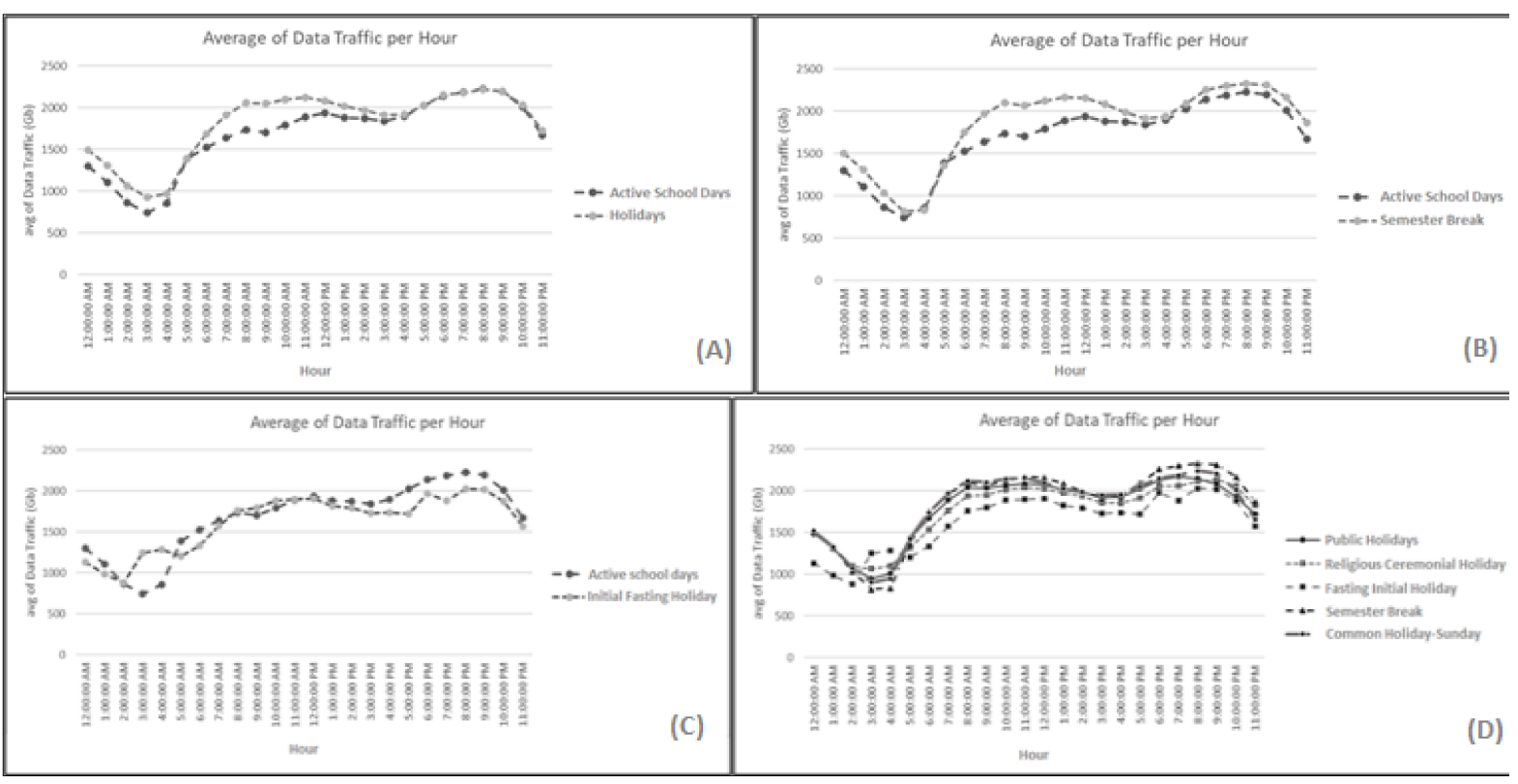

Fig. 9 Trends and patterns of The Internet use (A) School Active Days and all type of School Holidays, (B) School active days and semester break, (C) School active days and Initial fasting holiday, (D) all types of school holiday

\section{b. The Internet traffic payload trends and patterns between active school days and semester break}

In general, semester break is the longest school holiday period in Indonesia. Table 3 below describes the comparison of the Internet use between active school days and the semester break. Table 3 has similar highest and lowest peaks of the Internet use which is at 20.00 and at 03.00 . A significant increase of the Internet use (above 20\%) between the school active days and semester break is at $08.00-10.00$. As shown in the data, the increase rate in the average of the Internet use is still quite high (above 10\%) until 13:00, and it begin to decrease at 14.00.

Table 3 also showed that the average use of the Internet continues to increase significantly up to afternoon and evening. During the semester break, the average use of the Internet is quite high above than in school active days even until late midnight. Data visualization of Table 3 is presented in diagram (Fig. 9 (B)). It shows that for almost 22 hours during semester break, the Internet traffic payload keeps increasing significantly above the average use at school active days.

\section{c. The Internet traffic payload trends and patterns between active school days and initial fasting holiday}

During Ramadhan, the daily routines are changing. The data analysis is presented accordingly in Table 3 , where at 00.00 there is still fewer the Internet user and yet start to increase significantly at 3:00 to 4:00 which is commonly acknowledged as sahur time (early breakfast to mark the beginning of fasting). The Internet use then decreased significantly at 17.00, as it is time for breaking the fast, and at 19:00 during the Tarawih prayer time. The data visualization of Table 3 is presented in diagram (Fig. 9 (C)). It shows in general that the average the Internet use during initial fasting holiday is below of the average use at school active days.

\section{d. The Internet traffic payload trends and patterns between semester break and non-semester break}

Trends and patterns between all types of holidays differ from one another. As in previous section C, it is shown that during initial fasting holiday there is an anomaly, where the Internet use indeed decrease. As shown in Fig. 9 (D), there are indeed differences in trends and patterns resulting from the types of holiday. Yet, they are somewhat similat except for the initial fasting holiday. Further analysis aims to find out whether semester breaks still occupy the highest rate of the Internet use compared to other types of holiday. The results of data processing are presented in Table 4. Table 4 describe that for almost 20 hours during semester break, the average use of the Internet is above than the average use at non-semester break. The data visualization of Table 4 is presented in diagram at Fig. 10. 
TABLE 4

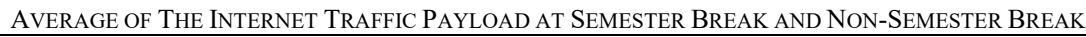

\begin{tabular}{|c|c|c|c|}
\hline \multirow{2}{*}{ Time } & \multicolumn{2}{|c|}{ Average of The Internet traffic Payload (GB) } & \multirow{2}{*}{ Traffic Delta (\%) } \\
\hline & Non-Semester Break & Semester Break & \\
\hline 1 & 2 & 3 & $4=((3 / 2) * 100)-100$ \\
\hline 00:00:00 & $1.449,54$ & $1.501,58$ & 3,59 \\
\hline 01:00:00 & $1.274,74$ & $1.311,87$ & 2,91 \\
\hline 02:00:00 & $1.058,78$ & $1.035,90$ & $-2,16$ \\
\hline 03:00:00 & $1.018,26$ & 818,42 & $-19,63$ \\
\hline 04:00:00 & $1.068,95$ & 832,58 & $-22,11$ \\
\hline 05:00:00 & $1.360,65$ & $1.357,98$ & $-0,20$ \\
\hline 06:00:00 & $1.583,88$ & $1.749,44$ & 10,45 \\
\hline 07:00:00 & $1.808,69$ & $1.967,95$ & 8,81 \\
\hline 08:00:00 & $1.971,49$ & $2.096,57$ & 6,34 \\
\hline 09:00:00 & $1.974,19$ & $2.062,75$ & 4,49 \\
\hline 10:00:00 & $2.023,27$ & $2.120,78$ & 4,82 \\
\hline 11:00:00 & $2.047,96$ & $2.162,44$ & 5,59 \\
\hline $12: 00: 00$ & $2.033,33$ & $2.155,17$ & 5,99 \\
\hline 13:00:00 & $1.979,35$ & $2.082,60$ & 5,22 \\
\hline 14:00:00 & $1.941,16$ & $1.987,70$ & 2,40 \\
\hline 15:00:00 & $1.871,53$ & $1.912,06$ & 2,17 \\
\hline 16:00:00 & $1.876,02$ & $1.938,69$ & 3,34 \\
\hline 17:00:00 & $1.949,25$ & $2.087,84$ & 7,11 \\
\hline 18:00:00 & $2.081,09$ & $2.255,44$ & 8,38 \\
\hline 19:00:00 & $2.094,02$ & $2.296,14$ & 9,65 \\
\hline 20:00:00 & $2.118,68$ & $2.326,50$ & 9,81 \\
\hline $21: 00: 00$ & $2.088,39$ & $2.308,81$ & 10,55 \\
\hline $22: 00: 00$ & $1.964,47$ & $2.164,44$ & 10,18 \\
\hline 23:00:00 & $1.736,74$ & $1.867,14$ & 7,51 \\
\hline
\end{tabular}

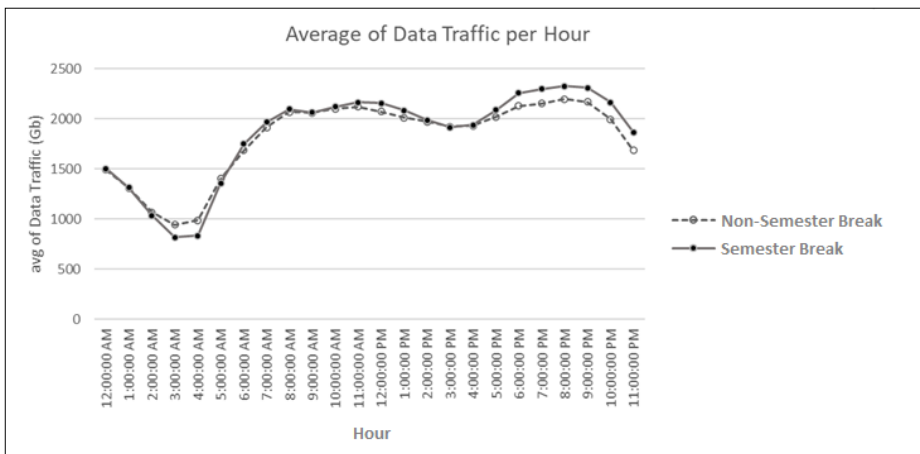

Fig. 10 Trends and patterns of the Internet use between semester break and non-semester break

\section{DISCUSSION}

Previous research [19] has shown the duration Internet use by students was around 2-3 hours per day. Most respondent sample majorities use the Internet during the office hours on campus by utilizing the free Wi-Fi facility. Previous research [20] also shows that only $37.1 \%$ of urban teenagers (respondents of junior and senior high school students in Surabaya) used the Internet to find reading sources and to complete school work, whilst the remaining students use the Internet for fun activities (chatting, playing online game, creating a social networking account, or even visiting pornographic sites). This figure is slightly better compared to research in the city of Surakarta in 2014 that shows only $17.5 \%$ of teenagers use it for school work [27]. The current study extends the findings from previous studies by analyzing the hour spend during school holidays.

The results show that the Internet use during school holidays tend to increase significantly at certain hours compared to school active days. These findings need to be considered by parents who provide the Internet facilities to their children, as whether full supervision and accompaniment to children has already been carried out, since the Internet have both positive and negative effects. Moreover, Indonesia has the second world highest case of cyberbullying [28], so parents are expected to give more attention to their children. 


\section{CONCLUSIONS}

In conclusion, nowadays the Internet is becoming a means of communication and information access that is widely used by students to spend their free time during school holidays. The research findings could be a point of reference for parents and teachers to limit and educate students in using the Internet in an orderly manner. Parents could provide extra supervision to their children while they are online. Teachers need to apply proper policy regarding the Internet use during the school hours.

\section{REFERENCES}

[1] M. Mihajlov and L. Vejmelka, "Internet addiction: A review of the first twenty years," Psychiatr. Danub., vol. 29, no. 3, pp. 260-272, 2017.

[2] A. P. Sari, A. Ilyas, and I. Ifdil, “Tingkat kecanduan internet pada remaja awal,” JPPI (Jurnal Penelit. Pendidik. Indones., vol. 3, no. 2, p. $45,2017$.

[3] N. Kurniasih, "Internet addiction, lifestyle or mental disorder? a phenomenological study on social media addiction in Indonesia," KnE Soc. Sci., vol. 2, no. 4, pp. 135, 2017.

[4] L. Fitria et al., "Exploring internet addiction on adolescents," J. Phys. Conf. Ser., vol. 1114, no. 1, 2018.

[5] N. N. Rahmat, "Duration of gadget usage affects eye fatigue in students aged 16-18 years," Heal. Notions, vol. 1, no. 4, pp. 335-340, 2017.

[6] S. T. Lee, J. E. Wong, S. N. Shanita, M. N. Ismail, P. Deurenberg, and B. K. Poh, "Daily physical activity and screen time, but not other sedentary activities, are associated with measures of obesity during childhood," Int. J. Environ. Res. Public Health, vol. 12, no. 1, pp. 146-161, 2015.

[7] E. Aboujaoude, M. W. Savage, V. Starcevic, and W. O. Salame, “Cyberbullying: review of an old problem gone viral,” J. Adolesc. Heal., vol. 57 , no. 1 , pp. $10-18,2015$.

[8] M. A. Ashraaf, N. Othman, M. A. Ashraaf, and N. Othman, "Factors for pornography addiction and its implication on teenager personality factors for pornography addiction and its implication on teenager personality," International Journal of Academic Research in Business and Social Sciences vol. 9, no. 11, pp. 1148-1160, 2019.

[9] APJII, "Penetrasi \& profil perilaku pengguna internet indonesia tahun 2018," APJII, p. 51, 2019.

[10] Bps.go.id, "Data Badan Pusat Statistik," Stat. Dasar Angka Partisipasi Kasar, vol. 2015-2018.

[11] P. Panjaitan and A. Prasetya, "Pengaruh social media terhadap produktivitas kerja generasi millenial ( studi pada karyawan PT . Angkasa Pura I cabang bandara internasional Juanda )," J. Adm. Bisnis, vol. 48, no. 1, pp. 173-180, 2017.

[12] D. Istri, "Hubungan antara kontrol diri dan dan keterampilan sosial dengan kecanduan internet pada siswa SMK," Pros. SEMNAS Penguatan Individu di Era Revolusi Inf., no. c, pp. 101-109, 2017.

[13] J. Dieris-Hirche et al., "Media use and internet addiction in adult depression: A case-control study," Comput. Human Behav., vol. 68, pp. 96-103, 2017.

[14] K. Schwab, Insight Report - World Economic Forum. 2019.

[15] P. A. Balland, R. Boschma, K. Frenken, I. Kakko, K. Mikkelä, and Solability, The Global Talent Competitiveness Index 2018, vol. 49, no. 6. 2018

[16] OECD, "PISA 2018 insights and interpretations," OECD Publ., p. 64, 2019.

[17] We Are Social \& Hootsuite, "Digital 2019: Essential insights into how people around the world use the internet, mobile devices, social media, and e-commerce," We Are Soc. Hootsuite, p. 76, 2019.

[18] S. Kemp, "Digital 2019: Indonesia-Data Reportal-Global Digital Insights," DataReportal, $2019 . \quad[$ Online]. Available: https://datareportal.com/reports/digital-2019-indonesia. [Accessed: 11-May-2020].

[19] I. Novianto, "Perilaku penggunaan internet di kalangan mahasiswa," Doctoral dissertation, Universitas Airlangga, 2013.

[20] A. N. Qomariyah, "Perilaku Penggunaan Internet Dikalangan Remaja Diperkotaan," Skripsi thesis, Universitas Airlangga, 2008.

[21] M. Djedaini et al., "Benchmarking exploratory OLAP," Technology Conference on Performance Evaluation and Benchmarking. Springer, Cham, 2016.

[22] M. Djedaini, K. Drushku, N. Labroche, P. Marcel, V. Peralta, and W. Verdeaux, "Automatic assessment of interactive OLAP explorations," Inf. Syst., vol. 82, pp. 148-163, 2019.

[23] J. C. Bou and A. Satorra, "Multivariate exploratory data analysis for large databases: An application to modelling firms' innovation using CIS data," BRQ Bus. Res. Q., vol. 22, no. 4, pp. 275-293, 2019.

[24] B. Agnihotri, "Designing and implementing result reporting tool using OLAP technology," International Journal of Advance Research, Ideas and Innovations in Technology, vol. 5, no. 3, pp. 1162-1166, 2019.

[25] I. Kovacic, C. G. Schuetz, S. Schausberger, R. Sumereder, and M. Schrefl, "Guided query composition with semantic OLAP patterns," CEUR Workshop Proc., vol. 2083, no. 848610, pp. 67-74, 2018.

[26] M. P. Cristescu, "Using OLAP data cubes in business intelligence," Sci. Bull., vol. 21, no. 2, pp. 80-86, 2017.

[27] O. Saputri, "Gambaran Penggunaan Internet Pada Anak," Naskah Publ. Univ. Muhammadiyah Surakarta, 2014.

[28] S. N. Hakim, A. A. Raj, and D. F. C. Prastiwi, "Remaja dan internet," Pros. SEMNAS Penguatan Individu di Era Revolusi Inf., 2017. 